\title{
Towards a better understanding of forgiveness of sins in the first commentaries on the Heidelberg Catechism
}

\author{
Author: \\ Pieter C. Potgieter ${ }^{1}$ \\ Affiliation: \\ ${ }^{1}$ Department of Systematic \\ Theology, University of the \\ Free State, South Africa \\ Correspondence to: \\ Pieter Potgieter \\ Email: \\ pcpotgieter@telkomsa.net \\ Postal address: \\ PO Box 271, Wilderness \\ 6560 , South Africa

\section{Dates:} \\ Received: 24 Aug. 2012 \\ Accepted: 25 Mar. 2013 \\ Published: 17 Sept. 2013 \\ How to cite this article: \\ Potgieter, P., 2013, 'Towards \\ a better understanding of \\ forgiveness of sins in the \\ first commentaries on the \\ Heidelberg Catechism', In die \\ Skriflig/In Luce Verbi 47(2), \\ Art. \#648, 6 pages. \\ http://dx.doi.org/10.4102/ \\ ids.v47i2.648

\section{Copyright:} \\ C 2013. The Authors. \\ Licensee: AOSIS \\ OpenJournals. This work \\ is licensed under the \\ Creative Commons \\ Attribution License.
}

Read online:

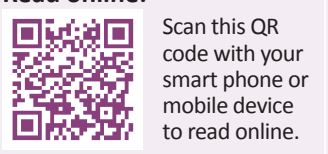

With regard to the issue of the forgiveness of sins in the Heidelberg Catechism, this paper shows that not only was there agreement and the same basic approach to issues of faith to be found in the commentaries of Ursinus and Olevianus, but also a valuable complementing of each other's work. The influence of Calvin, with whom both of them have studied in Geneva, is obvious in their doctrinal approach. Whereas Ursinus tended more towards an academic correctness in his Explicationum Catecheticarum, Olevianus added a pastoral and spiritual dimension in his Vester Grundt. Although some theologians questioned the role of Olevianus in the compilation of the Heidelberg Catechism, recent research adequately shows that both of them were indeed involved, and were well-endowed with the necessary background for providing a further exposition of the Catechism. Both of them emphasise the unquestionable and sole merit of Jesus Christ, through his vicarious death on the cross, as the only ground for God's gracious forgiveness of the sinner. It is God's free gift, appropriated through faith and trust in the merit of Christ.

'n Beter begrip van die vergifnis van sonde in die vroegste kommentaar op die Heidelbergse Kategismus. Hierdie artikel toon aan dat daar, wat die vergifnis van sonde betref, nie net groot ooreenstemming en dieselfde basiese benadering ten opsigte van geloofskwessies in die kommentare van Ursinus en Olevianus op die Heidelbergse Kategismus is nie, maar dat daar ook ' $n$ waardevolle wedersydse aanvulling van mekaar se werk is. Albei het by geleentheid in Genéve onder Calvyn gestudeer: sy invloed is onmiskenbaar in hulle leerstellige benaderings. In Ursinus se Explicationum Catecheticarum weeg die akademiese korrektheid swaarder, terwyl daar in Olevianus se Vester Grundt ook 'n pastorale en spirituele dimensie bykom. Olevianus se betrokkenheid by die opstel van die Heidelbergse Kategismus is soms sterk bevraagteken, maar nuwe navorsing laat genoegsaam blyk dat albei teoloë inderdaad deel gehad het daaraan, en ook goed toegerus was met die nodige agtergrond om 'n nadere verklaring van die Kategismus die lig te laat sien. Albei benadruk die onbetwisbare en enigste verdienste van Jesus Christus deur sy middellike dood aan die kruis as enigste grond vir God se genadige vergifnis van die sondaar. Dit is God se vrye guns, wat aangeneem word in geloof en vertroue deur die verdienste van Christus.

\section{First expositors of the Heidelberg Catechism}

In the Christian faith there is difference of opinion on the interpretation of the tenth article of the Apostles' Creed: the forgiveness of sins. The earliest commentaries on the Heidelberg Catechism, published by Zacharias Ursinus and Caspar Olevianus, bring more clarity on the intention of the Catechism. Both of them were traditionally seen as the cocontributors of the Catechism. The involvement of Olevianus has, however, been the subject of serious controversy amongst researchers over many years. The traditional view may primarily be attributed to Heinrich Alting's publication Historia Ecclesiae Palatinae in 1644. He stated that Elector Frederick III of the Palatinate assigned the composition of a catechism in German to these two Heidelberg theologians. Towards the end of the 19th and beginning of the 20th century, authors such as Sudhoff, Gooszen, Lauterburg, Cuno and Lang maintained that 'Olevianus was responsible for converting the rather heavily theological language of Ursinus's shorter catechism (Catechesis minor) into the warm, personal and practical style of the German Heidelberger' (Bierma 1982:18). Hollweg, however, seriously challenged this hypothesis in 1963, particularly on the grounds of an alleged serious lack of Olevianus's catechetical and linguistic skills (Hollweg 1961:124ff.).

Bierma made an in-depth study of the issue and concluded that modern historians have too quickly dismissed the above-mentioned Alting account as erroneous: Alting's father was a friend of Olevianus in Heidelberg and he certainly would not have passed on to his son unsubstantiated information as historical facts (Bierma 1982:20). Also interesting to note is that Olevianus wrote to Calvin in April 1563 regarding the work on the Catechism. It is quite clear that he was 
involved, when in this regard he says: 'Tanta est difficultas in conciliandis multis capitibus et redigendis in unum' [Such is the difficulty of reconciling from many heads and reducing them to one] (CO 19:685).

Bierma concludes that past solutions to the problem of Olevianus's authorship of the Heidelberg Catechism have all been partially correct and that Olevianus did prepare a rough draft of at least a section of the Catechism: (Alting 1702): ' $[H]$ e did convert at least part of the Latin text of the Catechesis minor into the German Heidelberger (Lang et al.); and he was not the final redactor of the Heidelberg Catechism (Hollweg)' (Bierma 1982:27). There is enough evidence to suggest that Olevianus might have prepared a draft of the German text of the Heidelberger (possibly Part II only), based largely on the Catechesis minor. He then submitted this to a larger body of theologians and pastors for final editing (Bierma 1982:27).

Both Ursinus and Olevianus were well-equipped to comply with the request of the Elector, and also to prepare a further exposition of the catechism.

After his theological studies with Melanchton at Wittenberg, Ursinus moved to Strasbourg, Zurich, Basel and Lausanne for further study under well-known reformation theologians, such as Bullinger. He then proceeded to Geneva, where Calvin presented him with a complete set of his works, signed by the author. In 1561 he came to Heidelberg as director of the Collegium Sapientiae theological academy by invitation of Frederick III. Shortly afterwards he was appointed as professor of dogmatics. After the death of Frederick III, the Lutheran Elector Louis dismissed the reformed faculty at the university and Ursinus moved on to Neustadt. His commentary on the Heidelberg Catechism was compiled from his lectures on the Catechism there and, sadly, was only published in 1584 after his death (Hanko 1999). It soon became a prominent theological handbook amongst seventeenth-century Reformed Christians and was often translated and reprinted. ${ }^{1}$ It was particularly popular amongst reformed German and Dutch immigrants to North America. In South Africa, copies of the leatherbound Dutch translation, Het schatboeck der verklaringhen over de Catechismus der Christelicke religie, can still be found as it was widely used in households for instruction on Sundays (Raath \& Erlank 2001:911; Van Zijl 1991:174).

Olevianus graduated from a Roman Catholic monastery school. He would always remember the words of an old priest (Hanko 1999): 'Never forget that salvation and comfort are to be found only in Christ's perfect work.' He then moved on to Paris to study law. His friendship with French Protestant students won him to the Reformation, and he proceeded to Switzerland where he met reformation leaders such as Beza, Bullinger, Farel and Viret. Most importantly, he studied under Calvin in Geneva. Whilst at Herborn, he taught a Latin outline of Calvin's Institutes that he had developed (Ehrenpreis 2009:435). He held a series of lectures at Trier - not in Latin, but in the German tongue. These lectures may be seen as the groundwork for an exposition of the catechism. After the city was attacked by archbishop John who restored Roman Catholicism, he was arrested and spent a short spell in prison. He was only released at the insistence of Elector Frederick III, on whose invitation he proceeded to Heidelberg in January 1560 where he completed his doctoral studies in theology. He was soon appointed to the chair of dogmatics in the Faculty of Theology at the university. When Ursinus arrived in late 1561, he relinquished his academic post to his new colleague. He was then installed as pastor of the local church and became the author of a number of treatises and books (Bierma 1995:xiv). ${ }^{2}$

The first edition of Olevianus's Vester Grundt was published by Michel Shirat of Heidelberg in 1567. In form, it was a quite lengthy catechism of 179 questions and answers, in which he 'sought to provide a solid doctrinal foundation for the spiritual comfort of troubled Christians in his day' (Bierma 1995:xv).

\section{Basic Roman Catholic teaching foreign to the Reformation}

What must be borne in mind is that, in those years, the Reformation was essentially a correction on Roman Catholic theology and practice. It is therefore essential to be clear on these teachings, as the Roman Catholic doctrine on the forgiveness of sins stands in strong contrast to the reformed doctrine, as clearly portrayed in the Heidelberg Catechism and commentaries on it.

In his exposition of the Apostles' Creed, Thomas Aquinas states categorically that Christ's communication of his good to all members of the Church:

... takes place through the Sacraments of the Church in which operate the merits of the passion of Christ, which in turn operates for the conferring of grace unto the remission of sins. These Sacraments of the Church are seven in number. (Aquinas 1939:Art. 10)

First and foremost is what happens through baptism:

The power of Baptism consists in this, that it cleanses from all sins (quod purgat ab omnibus peccatis) as regards both their guilt and their punishment. For this reason no penance is imposed on those who are baptized, no matter to what extent they had been sinners. (Aquinas 1939:Art. 10)

This view is confirmed by the Profession of Faith, promulgated by Pope Pius IV and the Council of Trent (1564): 'I confess one baptism for the remission of sins.'

Two more sacraments are also regarded as essential in this regard: Penance and Extreme Unction.

Three things must be present in the Sacrament of Penance: contritio [contrition], which is sorrow for sin together with a resolution not to sin again; confessio peccatorum [confession of sins], as far as possible entire; and et satisfactio quae est per bona opera [satisfaction which is accomplished by good works]. (Aquinas 1939:Art. 10)

The sacrament of Extreme Unction is likewise essential as 'no one can enter into eternal life until he is well cleansed' (nisi

2.For a biography of Ursinus and Olevianus, vide Chapter 29 (Zacharius Ursinus and Caspar Olevianus: Authors of the Heidelberg Catechism) from Hanko's Portraits of faithful saints (http://www.prca.org/books/portraits/ursinus.htm). 
sit bene purgatus) and prepared for entry into the heavenly kingdom. Thus Aquinas also states in his 'Summa Theologica': 'Therefore, just as Baptism is a spiritual regeneration, and Penance, a spiritual resurrection, so Extreme Unction is a spiritual healing or cure' (Aquinas 2009:Summa suppl., Q 30, Art. 1).

But how does this happen? The ministers of the church received the power to forgive sins as the power was first given to the Apostles: habeant potestatem ligandi atque solvendi [the Apostles received it from Christ; and thus the priests have the power of binding and loosing]. This happens from the pope down through the prelates (Aquinas 1939:Art. 10). The sacrament of Penance, for instance, is perfected by the priestly office of binding and loosing (Aquinas 1939:Summa pars 3, Q 86, Art. 2).

Even more is totally foreign to the Protestant faith: not only the efficacy of the passion of Christ is communicated to all who are in the state of grace, but also all the good that all the saints have done nam unus potest satisfacere pro alio [since one man can certainly satisfy for another] (Aquinas 1939:Art. 10).

Completely foreign to the Reformation was the Roman Catholic view as expressed by Thomas Aquinas: a bishop's blessing, the sprinkling of holy water, any sacramental anointing, a prayer said in a dedicated church, and anything else of the kind, conduce to the remission of venial sins (Aquinas 1939:Summa pars 3, Q 87, Art. 3).

\section{The Heidelberg Catechism}

In the original 1563 edition of the Heidelberg Catechism, Question 56 and its answer is as follows (see Figure 1):

\section{Frag [Question]}

Was glaubstu von vergebung der Sünden: [What do you believe concerning 'the forgiveness of sins'?]

\section{Antwort [Answer]}

Dass Gott vmb der gnugthuung Christi willen / aller meiner sunden / auch der sundlichen art / mit der ich mein lebenlang zu streiten habe / nimmermehr gedencken wil: sonder mir die gerechtigkeit Christi auss gnaden schencket / dass ich in gericht nimmermehr soll kommen. [I believe that God, because of Christ's satisfaction, will no longer remember any of my sins or my sinful nature that I need to struggle against all my life. Rather, by grace God grants me the righteousness of Christ to free me forever from judgment.]

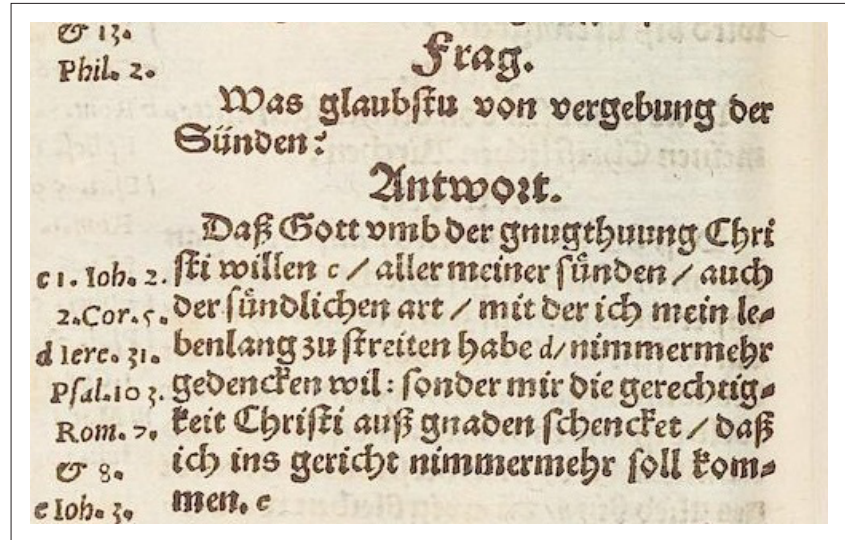

FIGURE 1: The original 1563 edition of the Heidelberg Catechism, Question 56.

\section{Ursinus's exposition of Question 56}

In Ursinus's exposition of Question 56 (1888:305ff.), he explains it under the following seven headings:

- What is the forgiveness of sins?

- By whom is it granted?

- On account of what is it granted?

- Does it comport with the justice of God?

- Is it gratuitous?

- To whom is it granted?

- How and when is it given?

God, according to his purpose, pardons deserved punishment on account of the righteousness and satisfaction of Christ. God loves the faithful and elect and remits unto them both the guilt and punishment of sin just as if they had not sinned. By the merits and intercession of Jesus Christ, he freely grants them eternal life. In this life, though, he still afflicts us - not as punishment, but that he may chastise us as a father. We must bear in mind that even though he has punished our sins in his son, they still greatly offend and displease him, and that even the omission of doing good is sin. But even so, he accounts us righteous on account of the satisfaction of Christ and by his merits alone. 'It is, therefore, the same thing to have the remission of sins, and to be righteous' (Ursinus 1888:306).

God alone - Father, Son and Holy Ghost - grants remission of sins, 'for no one can forgive sin, except the person against whom it is committed, and who is offended thereby' (Ursinus 1888:306). Ursinus states very clearly that 'no creature can grant anything which rightfully belongs to God' (Ursinus 1888:306). Against the Roman Catholic view that according to Matthew 18:18 and John 20:23 $3^{3}$ the apostles, and the church, remit sins, he answers that the apostles forgave sin only in as far as they announced the forgiveness of God. The church does pronounce forgiveness to the penitent, but Solus autem Deus liberat nos a reatu peccati $\mathcal{E}$ aeternae morris sua autoritate [God alone frees us from the guilt of sin by his own authority] (Ursinus 1593:282).

From several New Testament passages ${ }^{4}$ it is abundantly clear that 'God forgives our sins out of his pure mercy, and free love towards us; and on account of the intercession and satisfaction of Christ applied by faith' (Ursinus 1888:307). God would indeed yield somewhat of his justice, should intercession be made without satisfaction.

As a most righteous judge, God cannot permit sin to pass by with impunity. Unless some sufficient satisfaction is made, he cannot remit it out of mere clemency. He has, however, punished it most sufficiently in Christ. When God then pronounces us righteous, it Hoc autem non pugnat cum iustitia Dei [does not conflict with his justice and truth] (Ursinus 1593:283). To the objection that to punish the innocent in the place of the guilty is repugnant to the justice of God, Ursinus answers that the innocent one was of the same nature as the guilty: he was able to undergo a sufficient punishment, he could come forth from this punishment, he was willing to

3.John 20:23: 'Whosesoever sins ye remit, they are remitted unto them, and whosesoever sins ye retain, they are retained.

4.1 Pt 3:18; 1 Jn 1:7; Col 1:19, 20; Heb 12:24; Eph 1:7. 
endure the punishment which would be required and he was able to renew and regenerate the sinner, and give him faith so that he might embrace his benefits. For this he finds ample evidence in Scripture. $^{5}$

Although God demands satisfaction, 'he does not demand satisfaction from us, but from Christ upon whom our sins were laid' (Ursinus 1888:308). This satisfaction is indeed free in respect to us, because God gave this ransom for us, namely Christ our satisfier and mediator: 'for he was not purchased by us' (Ursinus 1888:308).

Only the sins of the elect are forgiven, because it is given to those who believe. According to the purpose of God, all the elect always have forgiveness of sins, but they do not always experience it (non semper quo ad ipsos) - only first when they are converted and faith is given to them. And although infants do not actually have faith, they have it in possibility and inclination (habent fidem $\mathcal{E}$ conversionem potentia $\mathcal{E}$ inclinatione, licet actu nondum credant, Ursinus 1593:287), and thus have forgiveness of sins.

Forgiveness of sins is granted and received by faith alone, but only as it is kindled by the Holy Spirit in us:

God has, indeed, determined from everlasting to pardon the sins of those whom he has chosen in Christ, for the sake of his satisfaction, but he pardons the sins of every one, and of all that believe in Christ, at the time when he accounts them as righteous, and works in their hearts by the Holy Spirit a sense of this pardon, so that they may forever remain certain in regard to it. (Ursinus 1888:309)

Although the decree of God in this regard is everlasting, it is only executed when we apply to ourselves the forgiveness, offered to us, by faith. Through the Holy Spirit they will have the testimony of their conscience 'that they are beloved of God, and so enjoy the forgiveness of sins' (Ursinus 1888:309).

\section{Olevianus's exposition of Question 56}

Olevianus's Vester Grundt [A firm foundation] was obviously, strictly speaking, not a commentary on the Heidelberg Catechism, but rather an exposition of the Apostolicum. On the other hand, it provides a far more detailed expansion of the Apostles' Creed's section in the Heidelberg Catechism than the catechism itself.

Way of comparison of relevant sections, Bierma convincingly argues that 'in theological content, structure and tone, the two documents are remarkably similar' (Bierma 1995:xviii). Olevianus frequently actually employs the same wording as found in the Heidelberger. In some instances Olevianus divided the content of a single question and answer in the Heidelberg Catechism and incorporated it into several longer questions and answers in the Vester Grundt for more detailed commentary (Bierma 1995:xx).

Olevianus deals with the forgiveness of sins in questions 138 through 145 of his Vester Grundt. He introduces the topic in Question 138:

5.Eph 5:2; Jn 10:15; Is 53:5; 2 Cor 5:15; In 2:19; $10: 17$; Eph 5:25;Tt 2:14.
How do you understand the possession of the benefits of Christ in this life?

I understand it as follows: just as there is no salvation outside of the Church, which is the body of Christ, so also all true and living members of the Church now possess true salvation, that is, forgiveness of sins (die wahre seligkeit / welche seligkeit wir gantz bes greiffen in der vergebung der sunden) (Olevianus 1567:173). The Apostle Paul proves this in Romans 4[:7,8] when he quotes Psalm 32[:1, 2]: 'Blessed are they whose transgressions are forgiven, and whose sins are covered. Blessed is the man whose sin God does not count against him'. See also Ephesians 2:12, 13 (Olevianus 1995:98f.). ${ }^{6}$

In the next question he asks for an explanation of the article 'I believe the forgiveness of sins.' One can clearly distinguish between residual sin (die vbrige sunde) and actual sins (wirckliche sunden) (Olevianus 1567:173). The former is the corrupt, evil disease that continues to hold me in its grip, preventing me to love God with all my heart or my neighbour as myself, whilst the latter are thoughts, words and deeds contrary to God's commandments. God has forgiven and pardoned these sins forever. Through the sacrifice of Christ on the cross God does this by grace and through faith in his promise. It is even verziegen das auch alle gedechtnutz [erased from God's mind] (Olevianus 1567:174) as though we have never sinned or had no sin. Through Christ, we may even now trust God for our salvation.

Olevianus leans very strongly on certain passages from Holy Scripture to comfort the faithful with certain promises of God concerning the forgiveness of sins, as our weak faith and faintness of heart needs to be strengthened. ${ }^{7}$

\section{The pastor's heart of Olevianus is evident in Question 141:}

Since there is nothing more difficult (nichts schwerers) to believe than the forgiveness of sins, give me some reasons or grounds on which to base our belief that believers are certainly forgiven of their sins. (Olevianus 1567:175, author's own translation)

The vicarious death of Christ is the confirmation of God's promise and oath (verheissung und eydt). No condition or merit (ohne verdienst der werck) on our side by keeping the commandments is required (Olevianus 1567:175): 'it is a free gift (ein frey geschenck) appropriated through faith or trust in the merit of Christ'.

As to whether we should then believe that there is no more sin in us, as our sins are forgiven, Olevianus responds with a very clear nein [no]. But even so it is not imputed (zugerechnet) to us, but fully pardoned. According to Romans 4 and Psalm 32, it is covered (bedeck) (Olevianus 1567:176).

In his next question, requiring an affirmative answer, Olevianus summarizes the article on the forgiveness of sins: whether you believe that the Church, the body of Christ, and all her members possess in this life that is certain, lasting and forever; mit denen sie teglich zu streiten haben [that it is true of all the sins with which the faithful have to struggle daily] (Olevianus 1567:177); and that believers have peace with God and thus true salvation.

6.Passages quoted are from the English translation by Bierma (Olevianus 1995:98-101).

7.Jr 31:34; 33:8; Ps 103:1-3; 10-12; 1 Jn 1:7; Jn 19:30. 
Next is a very practical question: shall we then continue to sin, since we know and believe that it is forgiven? The answer is no: far from it (das sey fern). All of us who are in Christ receive from him two benefits. The first, which we possess in this life, is the full remission of our sins. The second is that we are at the same time endowed with the Holy Spirit, 'who in this life begins to turn our hearts away from $\sin$ (der in diesem leben anfahet jre hertzen von den sunden ... abzuwenden) ... so that not sin but the Spirit of Christ prevails in us over sin to obey God the Lord and not sin' (Olevianus 1567:178).

Finally: do we obtain the forgiveness of sins by the merit of this new obedience, or good works? 'No. Both benefits are given to us freely, on account of the merit of Christ' (Olevianus 1995:101). What the Spirit does is to initiate in us obedience; not like a slave, but like a child. It is, however, incomplete in this life. The foundation of our salvation is only in the forgiveness of sins. 'This forgiveness is complete and thus covers what is deficient in our childlike obedience until such time as that deficiency is finally and completely removed' (Olevianus 1995:101). ${ }^{8}$

\section{The influence of Calvin on Ursinus and Olevianus}

As both Ursinus and Olevianus have spent time with Calvin in Geneva, without any doubt he obviously had a significant influence on their theology (Trueman 2009:476). Olevianus is known to have sought Calvin's advice on theological issues (Strohm 2009:403). Calvin's influence, particularly with regard to the sole satisfaction by Christ for the forgiveness of sins, is obvious. Calvin addressed this issue exhaustively in his exposition of the Apostolicum in his Institutes (Calvin 1559:3.20.45), as well as in his sermons to the Galatians.

He voiced his contempt for the Roman Catholic position on man's own merit and the mechanical working of the sacraments towards the remission of sin. The Papists, he says, states that quand nous sommes baptisez, que cela n'est que vertu [when we be once baptised, then all is virtue] (CO 51:38). ${ }^{9}$ This corresponds clearly with the views expressed in the works of Aquinas. ${ }^{10}$ They furthermore believe that one can deserve favour at God's hand and purchase remission of their sins (acquerir remission de leurs pechez); to achieve this they will clap you in the mouth with their Holywater (eau benite), their Tapers, their Sensings, their Organ plays, their chantings, their Pilgrimages and with a number of other things (CO 51:129). ${ }^{11}$

Calvin is known for his almost extreme emphasis on mankind's corruption and sinfulness. He calls sins 'debts', because we owe penalty for them (Peccata vero debita noncupat quod eorum poenam debemus, CO 2:671). He often emphasises the sin that dwells in us (du peché qui habite en nous, CO 50:296).

8.Der vergeburg der sunden welche volkommen ist / und also die mangel die noch an dem kindtlichen gehorsam seindt / bedeckt / bisz das sie endtlich gar hinweg genommen werden (Olevianus 1567:179)

9.Sermon on Galatians 5:19-23.

10.Vide above Aquinas 1939:Art. 10.

11.Sermon on Galatians 6:14-18.
In a sermon on Galatians 3:1-3, he worded it even more explicitly: Ne nous abusons plus donc en vaines flatteries, mais cognoissons que nous sommes du tout pervers en Adam, et qu'il n'y a en nous que peché [We must not beguile ourselves anymore with vain flatteries, but acknowledge ourselves to be utterly marred in Adam, so as there is nothing but sinfulness in us] (CO 50:465). And even more: we shall find enough wherewith to occupy ourselves in chastising our vices, if every one of us considered to how much corruption and sinfulness he is subjected to (de corruptions et de fautes il est suiet, CO 51:45).

It also remarkable that many of Calvin's prayers do not begin with a glorifying of God or thanksgiving, but with the acknowledgement of sin and a plead for forgiveness.

Although Ursinus and Olevianus do no shy away from mankind's inherited sinfulness, I do not find the same extremes as in Calvin, although the longing for remission and redemption is no less coveted. They would wholeheartedly agree with Calvin in his sermon to the Galatians (2:17-18) that quand nostre principal desir est de renoncer à ce qui est de vice en nous et de nostre chair [it is our chief desire to forsake the sinfulness that is in us] (CO 50:438). Calvin's complete rejection of mankind's own merit towards salvation, and the sole merit of Christ, is fully incorporated in their expositions. Both of them clearly followed Calvin's view that there is no one or nothing else taking away the sins of the world. 'Since he alone is the Lamb of God, he also is the sole offering for sins, the sole expiation, the sole satisfaction (Calvin 1559:3.4.26 - Solus quoque oblation est pro peccatis, solus expiation, solus satisfaction (CO 2:478)). Our Lord Jesus Christ will do away all our sins, so as they might no more come to account (abolir tous nos pechez, tellement qu'ils ne vinssent plus en conte, $\mathrm{CO}$ 50:451). No payment is required from us (nullum a nobis pretium accipiens, CO 2:671), ${ }^{12}$ because He took upon himself the penalty that we owe, and thus wiped out our guilt before God's judgement' (quod poenam nobis debitam in se transferens reatum nostrum deliverit coram Dei iudicio, CO 2:478).

Calvin also clearly rejects the notion of perfectionism as taught by some 'new doctors'. Although it pleases God gradually to restore his image in us, these theologians try to dazzle the simple and make them believe that they can render themselves completely free from guilt (CO 2:672). Once again, neither Ursinus nor Olevianus leave room for a perfect life where no remnants of sin are to be found.

Hesselink rightly points out that Calvin defines justification in terms of the forgiveness of sins - 'a dynamic reality resulting from our union with Christ' (Hesselink 2009:307). Forgiveness of sins is, according to Calvin, for us the first entry into the church and Kingdom of God. Without it, there is for us no covenant or bond with God:

Consequently, we must firmly believe that by God's generosity, mediated by Christ's merit, through the sanctification of the Spirit, sins have been and are daily pardoned to us who have been received and engrafted into the body of the Church. (Calvin 1559:4.1.21)

12.Calvin 1559:3.20.45. 
Likewise, when Olevianus states that there is no salvation outside of the church, the church is not the origin of salvation, but the result of salvation through the sole merit of Jesus Christ (Olevianus 1567:173). The church does not give redemption, but only pronounces it as grace in Christ (Ursinus 1593:282).

\section{Conclusion}

Ursinus's commentary and Olevianus's further exposition in his Vester Grundt not only show agreement and the same theological approach to basic issues of faith regarding the forgiveness of sins, but may also be seen as mutually complementing. Whereas in Ursinus we find a focus on the doctrinal correctness of what he wrote, Olevianus adds a pastoral and spiritual dimension to the exposition in this issue, which may be a cause of anxiety amongst the faithful.

Both Ursinus and Olevianus emphasise the unquestionable and sole merit of Jesus Christ through his vicarious death on the cross as the only ground for God's gracious forgiveness of the sinner. It is God's free gift appropriated through faith and trust in the merit of Christ.

There can be no doubt that both documents had far reaching effects, not only on believers in the early days of the Reformation, but even for generations to come. With these publications, Ursinus and Olevianus delivered a huge contribution to theological thought in the Reformation theology, which is reflected in the works of great theologians even to this day.

\section{Acknowledgments Competing interests}

The author declares that he has no financial or personal relationship(s) that may have inappropriately influenced him in writing this article.

\section{References}

Alting, H., 1702, Historia ecclesiae Palatinae, Francofurti ad Moenum.

Aquinas, T., 1939, Exposition in Symbolum Apostolorum. The Apostles' Creed, transl. Joseph B. Collins, (html-formatted by Joseph Kenny), viewed 20 June 2012, from http://www.josephkenny.joyeurs.com/CDtexts/Creed.htm\#10.

Aquinas, T., 2009, The Summa Theologica of St. Thomas Aquinas, rev. edn., transl. Fathers of the English Dominican Province (1920), online edition copyright by K. Knight, New Advent CD-ROM, edn. 2.1.

Bierma, L.D., 1982, 'Olevianus and the authorship of the Heidelberg Catechism: Another look', The Sixteenth Century Journal 13(4), 17-27. http://dx.doi.org/10.2307/2540007

Bierma, L.D. (transl. and ed.), 1995, A firm foundation: An aid to interpreting the Heidelberg Catechism, Baker Books, Grand Rapids.

Calvin, J., 1559, Institio Christianae Religio, Oliua Roberti Stephani, Geneva.

CO vide Calvin, J., 1863-1900, loannis Calvini opera quae supersunt omnia, G. Baum, E. Cunitz \& E. Reuss (eds.), Braunschweig. (= CR 29-87).

Council of Trent, 1564, 'Profession of Catholic faith', in Most Holy Family Monastery, viewed 16 March 2013, from http://www.mostholyfamilymonastery.com/Profession_ of_Catholic_Faith.html

Ehrenpreis, S., 2009, 'Education and pedagogy', in H.J. Selderhuis (ed.), The Calvin handbook, pp. 428-437, Eerdmans, Grand Rapids.

Hanko, H., 1999, 'Chapter 29: Zacharias Ursinus \& Caspar Olevianus: Authors of the Heidelberg Catechism', in The Protestant Reformed Churches in America, viewed 18 June 2012, from http://www.prca.org/books/portraits.

Hesselink, I.J., 2009, 'Pneumatology', in H.J. Selderhuis, The Calvin handbook, pp. 299-312, Eerdmans, Grand Rapids.

Hollweg, W., 1961, 'Bearbeitete Caspar Olevianus den deutschen Text zum Heidelberger Katechismus?', in W. Hollweg (ed.), Neue untersuchungen zur geschichte des Heidelberger Katechismus. Beitrage zur geschichte und lehre der Reformierten Kirche, vol. 13, pp. 124-152, Neukirchener Verlag, Neukirchen.

Olevianus, C., 1567, Vester Grundt, das ist, Die Artickel des alten, waren, ungezweiffelten Christlichen Glaubens, Michel Schirat, Heidelberg, viewed 26 June 2012, from http:// dfg-viewer.de/show/?set\%5Bimage $\% 5 \mathrm{D}=1 \&$ set $\% 5$ Bzoom $\% 5 \mathrm{D}=$ default\&set\%5B debug\%5 $\mathrm{D}=0$ \&set $\% 5$ Bdouble\%5D=0\&set $\% 5$ Bmets $\% 5 \mathrm{D}=\mathrm{http} \% 3 \mathrm{~A} \% 2 \mathrm{~F} \% 2 \mathrm{Fdaten}$ digitale-sammlungen.de\% $2 \mathrm{~F} \sim \mathrm{db} \% 2 \mathrm{Fmets} \% 2 \mathrm{Fbsb00035683 \_ mets.xml}$

Olevianus, C., 1995, A firm foundation. An aid to interpreting the Heidelberg Catechism, transl. L.D. Bierma (ed.), Baker Books, Grand Rapids.

Raath, A.W.G. \& Erlank, E., 2001, 'Die teologiese agtergronde van die Voortrekkergelofte (1838)', HTS 57(3\&4), 908-958.

Strohm, C., 2009, 'The law and canon law', in H.J. Selderhuis (ed.), The Calvin handbook, pp. 397-407, Eerdmans, Grand Rapids.

Trueman, C.R., 2009, 'Calvin and Reformed Orthodoxy', in H.J. Selderhuis (ed.), The Calvin handbook, pp. 472-479, Eerdmans, Grand Rapids.

Ursinus, Z., 1591, Erklärungen zum Heidelberger Katechismus, D. Pareus (ed.).

Ursinus, Z., 1593, Explicationvm Catecheticarvm. Pars altera, Studio Davidis Parei, Neustadt, viewed 25 June 2012, from http://dfg-viewer.de/show/?set\%5Bmets\% 5D=http\%3A\%2F\%2Fdaten.digitale-sammlungen.de\%2F\%7Edb\%2Fmets\% 2Fbsb00021605 mets.xml

Ursinus, Z., 1888, The Commentary of Dr. Zacharias Ursinus on the Heidelberg Catechism, transl. G.W. Williard, 4th American edn., Elm Street Printing, Cincinnati, viewed 12 June 2012, from http://archive.org/stream/commentaryofzach00ursiuoft/ commentaryofzach00ursiuoft_djvu.txt

Van Zijl, W.J., 1991, Van Skeepskis na Wakis tot Boekrak, Lux Verbi, Kaapstad. 